\title{
Effect of fertilizer levels on soil nutrient status at different growth stages and yield of $\mathrm{Bt}$ and non-Bt cotton
}

\section{R.S. MASRAM, A.A. PATIL, B.Y. SHEWALE AND S.R. KADAM}

\section{MEMBERS OF RESEARCH FORUM:}

Corresponding author : A.A. PATIL, Department of Soil Science and Agricultural Chemistry, Mahatma Phule Agricultural University, Rahuri, AHMEDNAGAR (M.S.) INDIA

Email: atishpatil53@gmail.com

\section{Co-authors :}

R.S. MASRAM, B.Y. SHEWALE AND S.R. KADAM, Department of Soil Science and Agricultural Chemistry, Mahatma Phule Agricultural University, Rahuri, AHMEDNAGAR (M.S.) INDIA
Received : 27.06.2014; Revised : 26.04.2015; Accepted : 05.05.2015

\section{Summary}

The Bt cotton is one of the outcome of gene revolution undertaken for production of cotton. Growing Bt cotton is proved as profitable as compare to non-Bt cotton which resulted in increase the area under cultivation of Bt cotton in Maharashtra as well as in India. The field experiment on effect of fertilizer levels on soil nutrient status at different growth stages and yield of Bt and non-Bt cotton was conducted at Cotton Improvement Project, Mahatma Phule Krishi Vidyapeeth, Rahuri during May to September, 2008. The experiment was laid out in Factorial Randomized Block Design with three replications and two main treatments i.e., hybrid Bt RCH-2 and Non-Bt RCH-2 and nine sub treatments with different fertilizer doses i.e., $\mathrm{F}_{1}$ - No recommended doses of fertilizer (RDF), $\mathrm{F}_{2}-50 \% \mathrm{RDF}, \mathrm{F}_{3}-75 \% \mathrm{RDF}, \mathrm{F}_{4}-100 \% \mathrm{RDF}$, $\mathrm{F}_{5}-125 \% \mathrm{RDF}, \mathrm{F}_{6}-150 \% \mathrm{RDF}, \mathrm{F}_{7}-100 \% \mathrm{RDF}+2 \% \mathrm{DAP}$ spray, $\mathrm{F}_{8}-100 \% \mathrm{RDF}+1 \% \mathrm{MgSO}_{4}$ and $\mathrm{F}_{9}-100 \% \mathrm{RDF}+1 \% \mathrm{KNO}_{3}$. The common $\mathrm{RDF}$ for $\mathrm{Bt}$ as well as non-Bt was $100 \mathrm{~N}, 50 \mathrm{P}_{2} \mathrm{O}_{5}$ and $50 \mathrm{~K}_{2} \mathrm{O} \mathrm{kg} \mathrm{ha}{ }^{-1}$. The results revealed that the Non-Bt hybrid at $100 \%$ NPK recorded maximum content of available nitrogen, potassium, magnesium and iron in soil as compared to Bt hybrid but except phosphorus which was more in Bt than non-Bt Non-Bt hybrid recorded maximum soil available nitrogen and potassium content in $\mathrm{F}_{9}\left(100 \% \mathrm{RDF}+1 \% \mathrm{KNO}_{3}\right)$ treatment at boll development stage as compared to Bt hybrid. However, magnesium and iron were maximum in $\mathrm{F}_{8}\left(100 \% \mathrm{RDF}+1 \% \mathrm{MgSO}_{4}\right)$ treatment in non-Bt as compared to Bt hybrid and phosphorus content was maximum in $\mathrm{F}_{7}(100 \% \mathrm{RDF}+2 \% \mathrm{DAP})$ treatment in $\mathrm{Bt}$ as compared to non-Bt hybrid at boll development stage. The application of $100 \% \mathrm{RDF}+1 \%$ $\mathrm{MgSO}_{4}$ spray recorded highest yield of $\mathrm{Bt}$ and non-Bt cotton hybrids.

Key words : Bt and non-Bt cotton, Yield, Soil nutrient status, Growth stages, Fertilizer levels

How to cite this article : Masram, R.S., Patil, A.A., Shewale, B.Y. and Kadam, S.R. (2015). Effect of fertilizer levels on soil nutrient status at different growth stages and yield of $\mathrm{Bt}$ and non-Bt cotton. Asian J. Soil Sci., 10(1) : 93-98. 